\title{
Potensi Kadar Neopterin sebagai Biomarker untuk Monitoring Kemajuan Terapi TB Paru pada Anak
}

\author{
Neopterin Level as a Biomarker on the Standard Therapy Progress Monitoring of Pulmonary TB Therapy \\ in Children
}

\author{
Aunillah ${ }^{1}$, TY Mardining Raras', HMS Chandra Kusuma \\ ${ }^{1}$ Laboratorium IImu Kesehatan Anak Rumah Sakit Umum Dr. Saiful Anwar Malang \\ ${ }^{2}$ Laboratorium Biokimia-Biomolekuler Fakultas Kedokteran Universitas Brawijaya Malang
}

\begin{abstract}
ABSTRAK
Kadar neopterin plasma ditemukan berhubungan dengan efikasi terapi pada tuberkulosis paru pasien dewasa. Penanda biologis untuk diagnosis tuberkulosis pada anak masih terus diteliti. Penelitian ini dilakukan untuk mengidentifikasi peran neopterin sebagai penanda biologis untuk mengevaluasi keberhasilan terapi standar tuberkulosis paru pada anak. Sebanyak 25 pasien dengan tuberkulosis paru diikuti selama enam bukan. Kadar neopterin plasma diukur dengan metode ELISA sebelum terapi, 2, 4, dan 6 bulan sesudah terapi. Sepuluh anak sehat ditetapkan sebagai kontrol. Hasil menunjukkan pada semua pasien kadar neopterin tertinggi didapatkan sebelum terapi dengan rerata 0,27 (SD 0,09 $\left.{ }^{\mathrm{c}}\right) \mathrm{ng} / \mathrm{mL}$. Kadar neopterin plasma pada kelompok kontrol $1,50(\operatorname{SD~} 0,18) \mathrm{ng} / \mathrm{mL}$, sebelum terapi $1,12(S D 0,22) \mathrm{ng} / \mathrm{mL}$, bulan kedua 1,08 $(S D 0,22) \mathrm{ng} / \mathrm{mL}$, bulan keempat 0,97 $(\mathrm{SD} 0,35) \mathrm{ng} / \mathrm{mL}$, dan bulan keenam 0,45 (SD 0,29) $\mathrm{ng} / \mathrm{mL}$. Kadar neopterin tertinggi didapatkan sebelum terapi yang kemudian menurun secara bertahap sesuai terapi bersamaan dengan perbaikan gejala klinis. Kadar neopterin pada kontrol lebih tinggi dibandingkan pasien selama masa pengamatan. Dapat disimpulkan kadar neopterin plasma mempunyai potensi sebagai biomarker kemajuan terapi tuberkulosis paru anak.
\end{abstract}

Kata Kunci: Anak, biomarker, neopterin plasma, terapi, tuberkulosis paru

\begin{abstract}
Neopterin plasma level found to be related with efecacy therapy of adult pulmonary tuberculosis, meanwhile biological marker for diagnosis of tuberculosis in children is still investigated. This research aim to identify neopterin role as biological marker to evaluate the succesfull of standart therapy on pulmonary tuberculosis in children. Twenty five children with pulmonary tuberculosis followed for 6 months, meanwhile 10 healthy children as control. Neopterin plasma measured with ELISA method before therapy, month of 2, 4, and 6 after therapy. Result of the research showed that all patients have high level of neopterin with the average of $0,27\left(S D 0.09^{c}\right) \mathrm{ng} / \mathrm{mL}$. Neopterin plasma level in control group 1,50 (SD 0,18) $\mathrm{ng} / \mathrm{mL}$, before therapy $1,12(S D 0,22) \mathrm{ng} / \mathrm{mL}$, second month $1,08(S D 0,22) \mathrm{ng} / \mathrm{mL}$, forth month 0,97 (SD 0,35) $\mathrm{ng} / \mathrm{mL}, \mathrm{and}$ sixth month $0,45(S D 0,29) \mathrm{ng} / \mathrm{mL}$. The highest level of neopterin was found in the group before therapy and decreasing gradually as the therapy process and clinical improvement. Neopterin level in the control group was higher compared to patient group for the observation duration. It can be concluded that neopterin plasma is potential for biomarker in children pulmonary tuberculosis therapy progression.
\end{abstract}

Keywords: Biomarker, neopterin plasma, pulmonary tuberculosis in children, therapy

Jurnal Kedokteran Brawijaya, Vol. 27, No. 4, Agustus 2013; Korespondensi: Aunillah. Laboratorium Ilmu Kesehatan Anak Rumah Sakit Umum Dr. Saiful Anwar Malang, Jl. Jaksa Agung Suprapto No. 2 Malang Tel. (0341)362101 Email: illahamid_dr@yahoo.com 


\section{PENDAHULUAN}

Tuberkulosis (TB) tetap merupakan salah satu penyebab tingginya angka morbiditas dan mortalitas, baik di negara berkembang maupun di negara maju (1). Indonesia menduduki peringkat kelima negara dengan beban TB tertinggi di dunia. Estimasi prevalensi semua kasus TB di Indonesia adalah sebesar 660.000 (73\%) dan estimasi insidensi berjumlah 430.000 kasus pertahun, sedangkan kasus TB anak pada tahun 2009 mencapai 30.806 $(10,45 \%)$. Angka-angka ini merupakan gambaran parsial dari keseluruhan kasus TB anak yang sesungguhnya karena untuk mendiagnosis TB anak sangat sulit, sehingga sering terjadi overdiagnosis atau underdiagnosis, dan pelaporan masih rendah dari fasilitas pelayanan kesehatan (2).

Sulitnya diagnosis pasti TB paru anak salah satunya disebabkan baku emas diagnosis mensyaratkan ditemukannya Mycobacterium tuberculosis ( $M$. tuberculosis) pada pemeriksaan hapusan langsung dari dahak, dan atau hasil biakan. Pada anak-anak dahak sulit dikeluarkan dan jumlah kuman sangat sedikit (paucibacillary) dan lokasi kuman didaerah parenkhim yang jauh dari bronkus. Berdasarkan hal ini evaluasi kemajuan pengobatan menjadi penting. Evaluasi bisa dilakukan dengan beberapa cara yaitu klinis, radiologis dan laboratorium. Evaluasi klinis merupakan metode yang paling banyak dipergunakan, berdasar pada menghilang atau membaiknya gejala klinis yang sebelumnya ada pada awal pengobatan. Apabila respon pengobatan baik, maka pengobatan dilanjutkan. Evaluasi kemajuan pengobatan TB pada penderita anak dilakukan setelah 2 bulan terapi (3). Evaluasi radiologis sangat sulit dilakukan, karena bersifat subjektif dan harus dibaca oleh dua orang ahli yang berpengalaman (4).

Beberapa tahun terakhir ini ditemukan dan diteliti beberapa biomarker untuk TB, diantaranya adalah neopterin. Neopterin merupakan biomarker yang diproduksi oleh makrofag yang teraktivasi oleh infeksi $M$. Tuberculosis (5). Biomarker ini cukup potensial untuk digunakan sebagai alat untuk mengevaluasi keberhasilan pengobatan TB karena memiliki beberapa keunggulan dibandingkan dengan metode konvensional yaitu lebih objektif, lebih mudah, sehingga anak-anak tidak harus mengeluarkan dahak, tidak harus difoto thoraks berulangulang yang dapat menyebabkan radiasi buat pasien. Biomarker ini ditemukan dicairan plasma penderita, sehingga pemeriksaan bisa dilakukan pada plasma darah penderita.

Neopterin adalah produk katabolik dari guanosine triphosphat (GTP), diproduksi dan dikeluarkan oleh makrofag melalui stimulasi dari Interferon gamma (IFN- - ). Interferon gamma dianggap sebagi satu-satunya sitokin yang bisa menginduksi produksi neopterin. Jika dalam tubuh terjadi gangguan aktifitas dari sellimfosit $\mathrm{T}$, misalnya ada antigen yang masuk dan terjadi respon imun dalam tubuh, yang mempengaruhi aktivasi dari makrofag, maka secara tidak langsung juga akan mempengaruhi pembentukan neopterin (6). Neopterin diproduksi dalam makrofag atau monosit tubuh dan selanjutnya akan dilepaskan ke dalam cairan plasmatubuh. Pengukuran kadar neopterin dalam plasma tidak hanya membantu memberikan informasi tentang keadaan sesungguhnya dari respon imun sel saja, tetapi bisa juga dipakai dalam monitoring perkembangan penyakit (7). Penelitian ini mengkaji potensi neopterin sebagai biomarker untuk mengevaluasi kemajuan pengobatan TB pada anak.

\section{METODE}

Penelitian ini dilakukan di Laboratorium/SMF IImu Kesehatan Anak RSU Dr. Saiful Anwar Malang dan Biomedik FKUB selama 12 bulan, sejak bulan Februari 2011 sampai dengan Januari 2012. Populasi penelitian ini adalah pasien anak denganTB paru yang datang ke instalasi rawat jalan Laboratorium/ SMF IImu Kesehatan Anak RSU Dr. Saiful Anwar Malang. Penderita TB paru anak baru merupakan penderita yang belum pernah minum obat anti tuberkulosis (OAT). Tuberkulosis paru dinyatakan positif pada mereka yang memenuhi skor $\geq 6$ pada sistem penilaian menurut Pedoman Nasional TB anak di Indonesia, Ikatan Dokter Anak Indonesia (IDAI), 2008. Dengan catatan skor $\geq 6$ didapatkan berdasarkan keluhan klinis, tidak berdasarkan hanya uji tuberkulin 3 dan kontak 3.

Kriteria inklusi subjek penelitian adalah pasien baru anak yang sudah terdiagnosa sebagai penderita TB paru berdasarkan skoring TB IDAI. Semua pasien usia antara 214 tahun dan teratur minum OAT. Kriteria eksklusi subjek penelitian adalah penderita TB paru anak yang mengidap penyakit lain seperti: HIV, penyakit jantung, diabetes melitus, pneumonia gangguan fungsi hati dan penyakit gagal ginjal. Serta 10 anak sehat sebagai kontrol. Subjek penelitian diikuti sebelum pengobatan, akhir bulan ke-2, 4, dan 6.

Pemberian obat pada penderita TB paru terdiri dari INH (5$15 \mathrm{mg} / \mathrm{kgBB} /$ har), rifampicin (10-20 mg/kgBB/hari), pyrazinamid (15-30 mg/kgBB/hari) selama 2 bulan untuk fase intensif. Untuk fase lanjutan diberikan INH, rifampicin selama 4 bulan. Keberhasilan respon klinis yang digunakan adalah bila ada perbaikan klinis dari keluhan pasien dengan perbaikan skoring maksimal 7 berdasarkan skoring TB menurut Pedoman Nasional TB anak di Indonesia IDAI, 2008 , kecuali nilai uji tuberkulin dan kontak TB. Bahan yang digunakan dalam penelitian ini adalah spesimen darah sebanyak $3 \mathrm{~mL}$ dari penderita baru sesuai kriteria inklusi yang didiagnosa TB paru anak. Kadar neopterin plasma diukur menggunakan ELISA kit IBL (Jerman) yaitu suatu simplified double monoclonal antibody sandwich assay.

Pada masing-masing kelompok data dilakukan uji ANOVA One Way yang dilanjutkan dengan uji LSD. Uji statistik dianggap bermakna apabila nilai $p \leq 0,05$. Uji statistik dilakukan dengan program SPSS for Windows v. 19,0 (SPSS Inc, USA). Semua pasien TB paru anak dan orang tuanya dijelaskan mengenai penelitian dan menyetujui berpartisipasi dalam penelitian ini (informed consent). Penelitian ini sudah disahkan oleh komite etik RSU Dr. Saiful Anwar Malang, Fakultas Kedokteran Universitas Brawijaya.

\section{HASIL}

Penelitian awal ini dilakukan untuk mengetahui kemampuan neopterin sebagai biomarker dalam evaluasi keberhasilan terapi standar pada penderita TB paru anak. Neopterin diukur pada plasma sampel penelitian. didapatkan 25 pasien TB paru anak yang memenuhi skoring TB anak $\geq 6$, dan telah memenuhi kriteria inklusi dan eksklusi serta 10 orang kontrol sehat. Karakteristik penderita berdasarkan jenis kelamin, umur, keluhan penderita dan gambaran radiologi foto toraks sebelum terapi.

Dari 25 orang sampel penelitian, pasien dengan keluhan batuk pada saat berobat ke rumah sakit mencapai $92 \%$ $(n=23)$ dan $8 \% \quad(n=2)$ yang tidak mengeluh batuk. 
Sebanyak $64 \%(n=16)$ pasien mengeluh panas $64 \%(n=16)$ sedangkan $36 \%(n=9)$ tidak mengeluh panas. Terdapat $60 \%(n=15)$ pasien yang menunjukkan ada gejala pembesaran kelenjar leher sedangkan $40 \%(n=10)$ tidak menunjukkan adanya pembesaran kelenjar leher. Seluruh sampel penelitian $(n=25)$ termasuk gizi kurang.

Tabel 1. Karakteristik subjek penelitian

\begin{tabular}{|c|c|c|c|c|}
\hline & akteristik & uensi (n) & Prosentase & (\%) \\
\hline & lah Sampel & 35 & $100 \%$ & \\
\hline & trol & 10 & $28,8 \%$ & \\
\hline • & Perempuan & 5 & $50 \%$ & \\
\hline • & Laki -laki & 5 & $50 \%$ & \\
\hline & npel & 25 & $71,4 \%$ & \\
\hline • & Perempuan & 18 & $72 \%$ & \\
\hline • & Laki - laki & 7 & $28 \%$ & \\
\hline & ur rerata & tahun & & \\
\hline • & Kontrol & tahun & & \\
\hline • & Sampel & tahun & & \\
\hline & Jhan batuk & tal (25) & $100 \%$ & \\
\hline - & Batuk & 23 & $92 \%$ & \\
\hline • & Tidak batuk & 2 & $8 \%$ & \\
\hline & Jhan panas & 25 & $100 \%$ & \\
\hline • & Panas & 16 & $64 \%$ & \\
\hline • & Tidak panas & 9 & $36 \%$ & \\
\hline & uhan pembesaran kelenjar leher & 25 & $100 \%$ & \\
\hline • & Ada & 15 & $60 \%$ & \\
\hline • & Tidak ada & 10 & $40 \%$ & \\
\hline & tus gizi & 25 & $100 \%$ & \\
\hline • & Kurang & 25 & $100 \%$ & \\
\hline - & Baik & 0 & $0 \%$ & \\
\hline
\end{tabular}

\section{Kadar Neopterin}

Pengukuran kadar neopterin dalam evaluasi keberhasilan terapi pada sampel yang diambil dari waktu ke waktu selama terapi yaitu pada kontrol 1,50 (SD 18) ng/mL. Pada kelompok sampel kadar neopterin awal sebelum pengobatan $1,12(\mathrm{SD} 0,22) \mathrm{ng} / \mathrm{mL}$, akhir pengobatan bulan ke 2 1,08 (SD 0,22)ng/mL, bulan ke 40,97 (SD $0,35) \mathrm{ng} / \mathrm{mL}$ dan bulan ke 60,45 (SD 0,29)ng/mL. Dapat disimpulkan kadar neopterin awal menurun secara bertahap pada 4 bulan pengobatan dan menurun secara drastis pada bulan ke 6, tetapi kadar neopterin pada kontrol jauh lebih tinggi bila dibandingkan awal maupun akhir pengobatan.

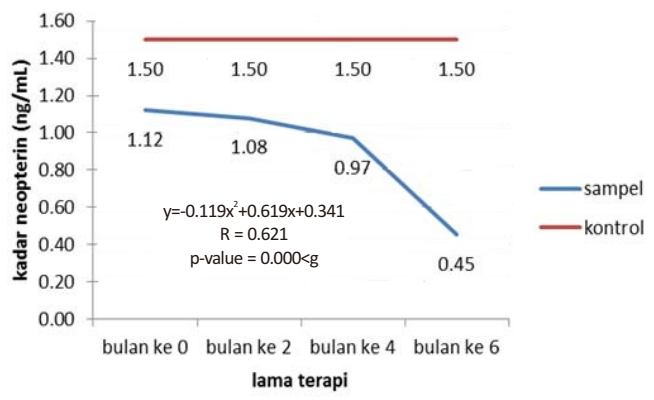

Gambar 1. Kadar neopterin selama pengobatan

Pengukuran kadar neopterin secara umum memperlihatkan kadar neopterin awal menurun secara bertahap pada 4 bulan pengobatan dan menurun secara drastis pada bulan ke-6, tetapi kadar neopterin pada kontrol jauh lebih tinggi bila dibandingkan awal maupun akhir pengobatan.

Tabel 2. Distribusi penderita berdasar parameter klinis dan lama terapi

\begin{tabular}{|c|c|c|c|c|c|}
\hline \multirow{2}{*}{ Karakteristik } & \multicolumn{4}{|c|}{ LamaTerapi } & \multirow{2}{*}{$\begin{array}{l}p \\
\text { value }<0,05\end{array}$} \\
\hline & Awal (0 bln) & Blnke-2 & Bln ke-4 & BInke-6 & \\
\hline \multicolumn{6}{|l|}{ Keluhan batuk } \\
\hline - $\quad$ Batuk & $23(92 \%)$ & $5(20 \%)$ & $2(8 \%)$ & $0(0 \%)$ & \\
\hline Tidak batuk & $2(8 \%)$ & $0(100 \%)$ & $0(100 \%)$ & $0(100 \%)$ & \\
\hline \multicolumn{6}{|l|}{ Keluhan demam } \\
\hline - Demam & $16(64 \%)$ & $0(100 \%)$ & $0(100 \%)$ & $0(100 \%)$ & \\
\hline - $\quad$ Tidak demam & $9(36 \%)$ & $0(100 \%)$ & $0(100 \%)$ & $0(100 \%)$ & \\
\hline \multicolumn{6}{|c|}{$\begin{array}{l}\text { Pembesaran kelenjar } \\
\text { limfe }\end{array}$} \\
\hline - $\quad$ Ada & $15(60 \%)$ & $12(48 \%)$ & $5(20 \%)$ & $2(8 \%)$ & \\
\hline - Tidakada & $10(40 \%)$ & $0(100 \%)$ & $0(100 \%)$ & $0(100 \%)$ & \\
\hline \multicolumn{6}{|l|}{ Status gizi } \\
\hline - $\quad$ Kurang & $25(100 \%)$ & $18(72 \%)$ & $3(12 \%)$ & $0(0 \%)$ & \\
\hline - $\quad$ Baik & $1(0 \%)$ & $7(28 \%)$ & $22(8 \%)$ & $25(100 \%)$ & \\
\hline $\begin{array}{l}\text { Kadar neopterin } \\
\text { mean }(\mathrm{SD})(\mathrm{ng} / \mathrm{mL})\end{array}$ & $1,12(0,22)$ & $1,08(0,22)$ & $0,97(0,35)$ & $0,45(0,29)$ & 0,00 \\
\hline
\end{tabular}

Distribusi penderita berdasarkan parameter klinis menunjukkan bahwa pasien yang datang dengan keluhan batuk pada awal pengobatan sebanyak $92 \%(n=23)$ dan membaik drastis pada akhir pengobatan bulan ke 2 sehingga hanya tinggal $20 \%(n=5)$. Tidak demikian dengan kadar neopterin yang menurun perlahan secara gradual dari awal pemeriksaan sampai bulan ke 2 . Hal yang sama terjadi pada 16 pasien yang datang dengan keluhan demam hanya ditunjukkan pada awal bulan ( 0 bulan), seiring berjalannya waktu terapi pengobatan menunjukkan tidak ada lagi keluhan demam pada akhir bulan ke-2, akhir bulan ke-4, dan akhir bulan ke-6. Kadar neopterin menurun perlahan secara gradual.

Lima belas pasien yang datang dengan keluhan adanya pembesaran kelenjar limfe selama terapi, mengalami perbaikan pada akhir bulan ke-2 $(n=3)$, akhir bulan ke-4 membaik sebanyak 7 orang, dan akhir bulan ke- 6 membaik sebanyak 5 orang, hanya 2 orang yang tanpa perbaikan. Hal ini paralel dengan menurunnya kadar neopterin yang menurun perlahan secara bertahap. Semua pasien datang dengan gizi kurang, mengalami perbaikan akhir bulan ke-2 $(n=7)$, akhir bulan ke-4 $(n=15)$, dan akhir bulan ke-6 semua pasien menjadi gizi baik, sebanding dengan penurunan kadar neopterin.

Perbandingan kadar neopterin dari waktu kewaktu antar kontrol 1,50 (SD 0,18 ${ }^{\mathrm{a}}$ ) $\mathrm{ng} / \mathrm{mL}$ dan 4 kelompok waktu pengamatan menunjukkan perbedaan yang bermakna $(p=0,00)$. Kadar neopterin pada awal pengobatan 1,12 (SD $\left.0,22^{b}\right) \mathrm{ng} / \mathrm{mL}$, akhir bulan ke 2 1,08 (SD 0,22 $\left.{ }^{b}\right) \mathrm{ng} / \mathrm{mL}$, akhir bulan ke $40,97\left(S D 0,35^{b}\right) \mathrm{ng} / \mathrm{mL}$ menunjukkan tidak ada perbedaan yang bermakna. Bila dibandingkan dengan kelompok pengamatan terapi akhir bulan ke $6(0,45$ SD $0,29^{\mathrm{c}} \mathrm{ng} / \mathrm{mL}$ ) menunjukkan ada perbedaan signifikan.

\section{DISKUSI}

Penelitian ini merupakan penelitian awal dengan metode cohort study untuk mengetahui kemampuan neopterin sebagai biomarker dalam evaluasi kemajuan terapi standard pada penderita TB paru anak. Neopterin diukur pada plasma sampel penelitian. Sebanyak 25 pasien TB 
paru anak yang memenuhi skoring TB anak $\geq 6$, dan telah memenuhi kriteria inklusi dan eksklusi serta 10 orang kontrol sehat. Sampel studi ini diikuti selama pasien minum OAT yaitu selama 6 bulan dan dilakukan evaluasi klinis, radiologis, dan laboratorium pada awal sebelum pengobatan, akhir bulan ke 2, akhir bulan ke 4, dan akhir bulan ke 6 . Kontrol tidak diikuti, pengambilan darah hanya dilakukan satu kali pada saat akan memulai running sampel penelitian.

Pada karakteristik sampel didapatkan rentang umur 2-12 tahun, dengan umur rerata 7,5 tahun, wanita $72 \%(n=18)$ lebih banyak dari laki-laki $28 \%(n=7)$ sesuai dengan penelitian yang dilakukan oleh Chandrawati (3). Batasan lokasi, waktu, kriteria inklusi dan eklusi serta faktor lain menyebabkan distribusi penderita berdasar jenis kelamin belum dapat dikatakan mewakili sebaran penyakit berdasar jenis kelamin secara umum.

Pasien yang datang dengan keluhan batuk pada awal pengobatan sebanyak $92 \%(n=23)$ dan membaik drastis pada akhir pengobatan bulan ke 2 hanya tinggal 20\% $(n=5)$, akhir bulan ke 4 hanya $8 \%(n=2)$, pada akhir bulan ke 6 tidak ada yang mengeluh batuk. Hal ini sama dengan penelitian yang dilakukan oleh Yani yang melakukan penelitian dengan menggunakan sistem skoring TB. Yani menemukan bahwa sebagian pasien yang terdiagnosa TB tidak semua mengeluh batuk dan yang mendapat terapi TB keluhannya menurun secara drastis pada akhir bulan ke 2 (8).

Enam belas pasien yang mengeluh demam hanya ditunjukkan pada awal bulan dan sudah tidak demam pada akhir bulan ke-2. Keluhan demam sudah tidak didapatkan, kemungkinan disebabkan efek bakterisidal OAT, sehingga tidak ada antigen yang bisa merangsang produksi sitokin atau adanya protective immunity yang diperankan oleh sitokin Th1 $(9,10)$

Secara umum ditemukan bahwa pasien yang mengeluh demam dan batuk mengalami perbaikan klinis yang signifikan pada akhir pengobatan bulan ke 2 . Keluhan batuk lebih menonjol pada dewasa karena fokus primer TB paru anak umumnya didaerah parenkim paru yang tidak mempunyai reseptor batuk dan produksi sekret anak sedikit karena kuman bersifat paucybacillary (11). Pada penelitian ini ditemukan bahwa keadaan klinis sampel penelitian yang datang dengan keluhan pembesaran kelenjar leher dan semua pasien dengan gizi kurang mengalami perbaikan secara perlahan bersamaan dengan nilai kadar neopterin yang berkurang secara gradual, sedangkan pasien yang datang dengan keluhan demam dan batuk mengalami perbaikan klinis yang drastis pada akhir pengobatan bulan ke 2, tidak bersamaan dengan berkurangnya kadar neopterin yang bertahap.

Hasil penelitian menunjukkan bahwa pola kadar

\section{DAFTAR PUSTAKA}

1. Cissy BK dan Darfioes B. Tuberkulosis: Epidemologi. Di dalam: Nastiti NR, Bambang S, Darmawan BS, penyunting. Buku Ajar Respirologi Anak edisi 1. Jakarta: Badan Penerbit IDAI; 2008; 162-166.

2. Direktorat Jenderal Pengendalian Penyakit dan Penyehatan Lingkungan Kementerian Kesehatan Republik Indonesia. Strategi Nasional Pengendalian $\mathrm{Tb}$ di Indonesia 2010-2014. Jakarta: Direktorat neopterin tertinggi didapatkan pada awal sebelum pengobatan dan menurun secara gradual dan kadar neopterin pada bulan keenamlah yang paling rendah. Turgut et al yang meneliti kadar serum IL-2 dan neopterin pada penderita TB paru pada populasi di Turki (dari hasil BTA dan/kultur sputum) sebelum dan sesudah terapi dibandingkan kelompok kontrol (orang sehat) didapatkan penurunan pada bulan 2, bulan ke 4, dan bulan ke 6 signifikan di bandingkan dengan kelompok kontrol (7). Begitu juga Immanuel et al dan Hosp et al mendapatkan bahwa kadar serum neopterin penderita TB paru berkurang secara perlahan pada saat mulai diagnosis sampai selesai masa terapi, dan lebih menonjol nilainya terutama pada kasus TB yang sedang hingga berat. Hal ini diduga karena terjadi aktivasi respon imun yang kuat pada pasien dengan TB berat $(12,13)$

Kadar neopterin pada kelompok kontrol dalam penelitian ini ditemukan lebih tinggi daripada sampel penelitian pada empat waktu pengukuran, namun masih berada dalam kisaran kadar neopterin yang normal, begitu juga kadar neopterin pada sampel selama masa terapi. Kadar neopterin kontrol lebih tinggi dari sampel kemungkinan karena adanya infeksi lain baik parasit maupun jamur atau bakteri lain yang bersifat laten (14). Penyebab lainnya karena pengambilan darah kontrol tidak bersamaan dengan sampel. Darah kontrol diambil pada saat semua sampel sudah selesai diikuti dan mendekati running penelitian. Kemungkinan bisa juga disebabkan peningkatan kadar neopterin dikarenakan infeksi virus lebih tinggi daripada yang disebabkan bakteri $(15,16)$. Penelitian yang dilakukan oleh Ryu et al menemukan neopterin serum pada kontrol sehat lebih tinggi bila dibandingkan dengan pasien TB. Neopterin serum pada kontrol berkisar 4,9 $\mathrm{ng} / \mathrm{mL}$ sedangkan pada sampel berkisar 2,9 ng/mL. Pada penelitian tersebut didapatkan penurunan kadar neopterin seiring dengan membaiknya keadaan klinis (17).

Kisaran kadar neopterin kontrol yang dilakukan beberapa studi pada anak normal berturut-turut $13,5 \mathrm{nmol} / \mathrm{L}(3,4$ $\mathrm{ng} / \mathrm{mL})(18), 10 \mathrm{nmol} / \mathrm{L}(2,53 \mathrm{ng} / \mathrm{mL})(19), 11 \mathrm{nmol} / \mathrm{L}$ (2,8 $\mathrm{ng} / \mathrm{mL}$ ) (14). Hal ini memperkuat dugaan bahwa kadar neopterin dipengaruhi oleh faktor genetik.

Dari penelitian ini dapat disimpulkan bahwa pengobatan OAT pada penderita tuberkulosis paru dengan regimen standar berpengaruh secara bermakna terhadap penurunan kadar neopterin bersamaan dengan respon perbaikan klinis walaupun yang sejalan hanyalah pembesaran kelenjar limfe yang membaik secara gradual. Neopterin tidak dapat digunakan sebagai biomarker tunggal tanpa indikator yang lain. Kadar neopterin penderita yang tinggi dapat dihubungkan dengan prognosa yang buruk sehingga diperlukan pemeriksaan klinis lebih lanjut sebagai antisipasi.

Jenderal Pengendalian Penyakit dan Penyehatan Lingkungan Kementerian Kesehatan Republik Indonesia; 2011.

3. Chandrawati H. Hubungan Body Mass Index dan Laju Endap Darah (LED) pada Penderita Tuberkulosis Paru Sesudah Pengobatan Antituberkulosis 6 bulan. [Tesis]. Universitas Brawijaya, Malang. 2006.

4. Graham SM, Ahmed T, Amanullah F, et al. Evaluation of Tuberculosis Diagnostics in Children: Proposed Clinical 
Case Definitions for Classification of Intrathoracic Tuberculosis Disease. Consensus from an expert panel. The Journal of Infectious Disease. 2012; 205(2): 199-208.

5. Wallis RS, Pai M, Menzies, D, et al. Biomarkers and Diagnostics: Progress, Need, and Translation Into Practice. The Lancet. 2010; 357(9729): 1920-37.

6. Murrs, C, Widner B, Wirleitner B, and Fuchs D. Neopterin as a Marker for Immune System Activation. Current Drugs Metabolism. 2002; 3(2): 175-187.

7. Turgut $\mathrm{T}$, Akbulut $\mathrm{H}$, Deveci F, Kacar $\mathrm{C}$, and Muz MH. Serum Interleukin-2 And Neopterin Levels as Useful Markers for Treatment of Active Pulmonary Tuberculosis. The Tohoku Journal of Experimental Medicine. 2006; 209(4):321-328.

8. Yani FF, Machmoed R, Marhefdison, dan Darfioes Basir. Tuberculosis Score Chart Signs And Symptoms In Children With Positive Tuberculin Skin Tests. Paediatrica Indonesiana. 2012; 52(2): 78-85.

9. Alsagaff H dan Mukty A. Dasar-Dasar Ilmu Penyakit Paru. Surabaya: Airlangga University Press; 2002.

10. Rom WN and Garay SM. Tuberculosis. 2nd edition. Philadelphia: Lippincot Williams and Wilkins; 2004; p. 251-379.

11. Juffermans NP, Verbon A, van Deventer SJ, et al. Elevated Chemokine Concentrations in Sera of Human Immunodeficiency Virus (HIV) Seropositive and HIV Seronegativeand Hivseronegative Patiens with Tuberculosis: A Possible Role for Mycrobacterial Lipoarabinomannan. Infection and Immunity. 1999; 67(8): 4295-4297.
12. Immanuel C, Rajeswari R, and Rahman F. Serial Evaluation of Serum Neopterin in HIV Seronegative Patients Treated for Tuberculosis. The International Journal of Tuberculosis and Lung Disease. 2001; 5(2): 185-190.

13. Hosp M, Elliot AM, Raynes JG, et al. Neopterin, $\beta 2-$ Microglobulin, and Acute Phase Protein in HIV-1Seropositive and Seronegative Zambian Patients with Tuberculosis. Lung. 1997; 175: 265-275.

14. Plata-Nazar K and Jankowska K. Clinical Usefulness of Determining the Concentration of Neopterin. Pteridines. 2011; 22: 77-89.

15. Fuchs D, Hausen A, Kofler M, Kosanowski $H$, Reibnegger G, and Wacther H. Neopterin as an Index of Immune Response in Patients with Patients with Tuberculosis. Lung. 1984; 162: 337-346.

16. Horak E, Gassner I, Soelder B, WachterH, and Fuchs D. Neopterin Levels and Pulmonary Tuberculosis $n$ Infants. Lung. 1998; 176(5): 337-344.

17. Ryu JY, Ryu KH, Kim SH, Lee JS, Cheon SH, and Seoh JY. Soluble IL-2R, IFN gamma, and Neopterin as Immunologic Markers in Patients with Tuberculosis. Tuberculosis and Respiratory Disease. 2002; 53(3): 294-308.

18. Werner E, Bichler A, Daxenbichler G, et al. Determination of Neopterin in Serum and Urine. Clinical Chemistry. 1987; 33(1): 62-66.

19. Millner MM, Franthal W, Thalhammer G, et al. Neopterin Concentrations in Cerebral Fluid and Serum as an Aid in Differentiating Central Nervous System and Peripheral Infections in Children. Clinical Chemistry. 1998; 44(1): 161-167. 